\title{
Production and Quality of Seven Basil (Ocimum basilicum L.) Accessions in Various Composition of Urea Fertilizer and Mexican Sunflower Compost
}

\author{
Arifah Rahayu $^{1 *}$, Nur Rochman ${ }^{1}$, Wini Nahraeni ${ }^{2}$, Nida Fitriasari $^{1}$ \\ ${ }^{1}$ Agrotechnology Study Program, Faculty of Agriculture, University of Djuanda, Indonesia \\ ${ }^{2}$ Agribusiness Study Program, Faculty of Agriculture, University of Juanda, Bogor, Indonesia \\ *Corresponding author. Email: arifah.rahayu@unida.ac.id
}

\begin{abstract}
The environmentally friendly fertilizer is necessary for vegetable production that are safe for consumption and maintain soil fertility. This study aims to determine the effect of the composition of urea fertilizer and Mexican sunflower compost (MSC) on the production and quality of various basil accessions (Ocimum basilicum L.). This study uses a factorial completely randomized design, namely basil accession (Gegerbitung, Kadudampit 1, Kadudampit 2, Kemang, Ciaruteun, Cijujug, and Gasol) and the composition of N fertilizer (100\% N-urea, 100\% N-MSC, $75 \% \mathrm{~N}$-urea + 25\% N-MSC, 50\% N-urea + 50\% N-MSC, 25\% $\mathrm{N}$-urea $+75 \% \mathrm{~N}-\mathrm{MSC}$, and $0 \% \mathrm{~N}$-urea $+0 \% \mathrm{~N}-\mathrm{MSC}$ ). The results showed that plants Kadudampit 2 and Gasol have growth and production better than other accessions. Plants treated with $100 \%$ N-MSC produced growth and harvest wet and dry weight not significantly different from $100 \% \mathrm{~N}$-urea. Nitrate and vitamin $\mathrm{C}$ content were not significantly different between accessions. The use of 100\% MSC significantly reduces leaf nitrate content. The vitamin $\mathrm{C}$ content was not significantly different between plants that were fertilized with various compositions of $\mathrm{N}$. The content of chlorophyll a, chlorophyll $\mathrm{b}$, and carotenoids of Gasol and Ciaruteun accessions were the lowest compared to the other five accessions. The highest chlorophyll a, chlorophyll $\mathrm{b}$ content are found in plants with Urea, followed by those given a combination of Urea + MSC. The carotenoid content of plant treated with $100 \%$ Urea was not significantly different from those fertilized with $75 \%$ Urea $+25 \%$ MSC and $25 \%$ Urea $+75 \%$ MSC.
\end{abstract}

Keywords: Basil, nitrate, vitamin C, chlorophyll, carotenoids

\section{INTRODUCTION}

Basil (Ocimum basilicum L.) is a local vegetable that is commonly consumed fresh, mixed with cooking, and used as a biopharmaceutical or ornamental plant. Basil leaves have distinctive aroma from their essential oils. Traditionally, the essential oil of basil used as an antispasmodic, aromatic, carminative, digestive, and gastric agent [1]. The content of active compounds in basil leaves can optimize health and reduce the risk of chronic diseases such as coronary heart disease, cancer, and Alzheimer's [2].

Basil is an annual herbaceous plant (Blank et al. 2012) [3],bush-shaped. This plant grows upright until it reaches $100 \mathrm{~cm}$ in height [4]. The nutritional content in $100 \mathrm{~g}$ of basil leaves consists of $94 \mathrm{KJ}$ of energy, $2.65 \mathrm{~g}$ of carbohydrates, $3.15 \mathrm{~g}$ of protein, $1.6 \mathrm{~g}$ of fiber, $0.64 \mathrm{~g}$ of fat, $0.8 \mathrm{mg}$ of vitamin E, $18 \mathrm{mg}$ of vitamin C, $5275 \mathrm{SI}$ vitamin A, $177 \mathrm{mg} \mathrm{Ca}, 56 \mathrm{mg} \mathrm{P}, 3.17 \mathrm{mg} \mathrm{Fe}, 259 \mathrm{mg} \mathrm{K}$,
$0.81 \mathrm{mg} \mathrm{Zn,} 3142 \mu \mathrm{g}$ beta-carotene, $0.034 \mathrm{mg}$ thiamin, $0.092 \mathrm{mg}$ niacin [5].

Growth, production, and quality of basil are influenced by climatic factors and cultivation techniques, including fertilization. A nutrient that plays an essential role in the growth of leafy vegetables is nitrogen. The application of nitrogen fertilizers can increase the production and fresh weight of basil [6]. Applying fertilizer with the right dose can increase plant height, dry weight, and essential oil content of basil plants [7]. However, too high an amount of nitrogen fertilizers can reduce plant height and leaf width, thus affecting wet weight and dried basil plants [6].

Plants absorbed nitrogen in the form of nitrate and ammonium. Generally, farmers use Urea as a nitrogen source, so that Urea is the most widely used nitrogen fertilizer globally, with a content of $46 \% \mathrm{~N}$ [8]. The application of Urea fertilizer can directly increase 
plant productivity, especially leafy vegetables [9]. In rice, the dosage of Urea use by farmers can reach 400-600 $\mathrm{kg} / \mathrm{ha}$,Generally, farmers use urea as a nitrogen source, so that urea is classified as the most widely used nitrogen fertilizer in the world, with a content of $46 \% \mathrm{~N}$ [8] The application of urea fertilizer can directly increase plant productivity, especially leafy vegetables [9]. In rice, the dosage of urea use by farmers can reach $400-600 \mathrm{~kg} / \mathrm{ha}$, exceeding the government's recommended dosage of $200-260 \mathrm{~kg} / \mathrm{ha}[10]$

The use of Urea fertilizers with high doses can increase the nitrate content in the soil, which causes groundwater pollution [11]. Too high absorption of nitrates by plants adversely affects the health of humans who consume them [12]. The use of environment from high chemical exposure can be done by providing a source of organic nitrogen, including using Mexican sunflower compost (MSC).

Mexican sunflower (Tithonia diversifolia) is a herbaceous plant from the Asteraceae family that used as green manure, liquid organic fertilizer, and compost [13]. Mexican sunflower contains $3.50-4.00 \%$ N, 0.35 $0.38 \% \mathrm{P}, 3.50-4.10 \% \mathrm{~K}, 0.59 \% \mathrm{Ca}$, and $0.27 \%$ $\mathrm{Mg}$ [14]. This plant has a faster decomposition time than others a high potential for restoring soil fertility [15]. Mexican sunflower compost can be an alternative to nitrogen fertilizers that can replace or reduce the use of Urea fertilizers. This study aims to evaluate the growth, production, and quality of various accessions of basil (Ocimum basilicum L.) on various composition of Urea and Mexican sunflower compost.

\section{MATERIALS AND METHODS}

The research was conducted from February to May 2020. The temperature conditions in the field ranged from $22-34{ }^{\circ} \mathrm{C}$, with an average humidity of $80 \%$. The study took place during the rainy season, with an average rainfall of $517 \mathrm{~mm} / \mathrm{month}$ [16]. The field experiment was carried out at the Experimental Garden of the Agrotechnology Study Program, Faculty of Agriculture, Djuanda University, Bogor. Analysis of leaf nitrate and vitamin $\mathrm{C}$ content was conducted in the laboratory of the Faculty of Agriculture, Djuanda University, leaf chlorophyll content in the Testing Laboratory of the Department of Agronomy and Horticulture of IPB, and analysis of nutrients and fertilizers at the ICBB (Indonesian Centerfor Biodiversity and Biotechnology) laboratory Bogor.

\subsection{Tools and Materials}

Materials used are basil accessions from Sukabumi district (Gegerbitung, Kadudampit1 and Kadudampit2), Bogor district (Kemang, Ciaruteun, and Cijujug), and Cianjur (Gasol), polybags, medium planting (soil and husk charcoal), MSC, synthetic fertilizers (Urea, SP- 36, and $\mathrm{KCl}$ ), insecticides, distilled water, ingredients for analysis of vitamin $\mathrm{C}$ (starch and iodine solution), chlorophyll (extract acetone and Tris $\mathrm{HCl} 1 \%$ ).

\subsection{Research Methods}

This study used a completely randomized design (CRD) consisting of two factors, namely basil accession and a combination of $\mathrm{N}$ fertilizers. Basil accessions consisted of seven levels, namely Gegerbitung, Kadudampit 1, Kadudampit II, Kemang, Ciaruteun, Cijujug, and Gasol. The combination of $\mathrm{N}$ fertilizer consists of six levels, namely $100 \% \mathrm{~N}$-urea, $100 \% \mathrm{~N}$ Mexican sunflower, $75 \% \mathrm{~N}$-urea $+25 \% \mathrm{~N}$-Mexican sunflower, $50 \% \mathrm{~N}$-urea $+50 \%$ Mexican sunflower, $25 \%$ $\mathrm{N}$-urea $+75 \% \mathrm{~N}$-Mexican sunflower, $0 \% \mathrm{~N}$-Urea $+0 \%$ $\mathrm{N}-$ Mexican sunflower. The dose of $\mathrm{N}$ fertilizer used was $150 \mathrm{~kg} \mathrm{~N} \mathrm{ha}{ }^{-1}$. The experiment consist of 42 treatment combinations, with three replications. Each experimental unit consists of four observation units, so there are 504 observation units $(7 \times 6 \times 3 \times 4)$.

Data were analyzed using variance (Test $F$ ). If the treatment had a significant effect, means compared with Duncan's Multiple Range Test (DMRT) at the 0.05 level.

\subsection{Research Implementation}

Mexican sunflower compost is done by mixing 25 $\mathrm{kg}$ of chopped fresh Mexican sunflower leaves with $100 \mathrm{~g}$ of bran, 25g of granulated sugar dissolved in water, and $5 \mathrm{ml}$ of EM4. The mixed compost is stored in perforated trash bag and left for three weeks.

Sowing basil seeds for two weeks. Then the seeds are transferred to polybags measuring $10 \times 20 \mathrm{~cm}$. Transplanting the seedlings into polybags measuring 30 $\mathrm{cm} \times 40 \mathrm{~cm}$ is done at the age of four weeks after seeding. The planting medium used for the nursery and planting is a mixture of soil and husk charcoal with a volume ratio of 1 : 1. Watering, controlling pests, diseases, and weeds were carried out according to agricultural cultivation standards.

Fertilization is given based on the level of treatment. Urea fertilization is carried out gradually; $50 \%$ as a primary fertilizer and $25 \%$ as an additional fertilizer at the age of 3 and 6 weeks after planting (WAP). Mexican sunflower compost is given at once a week before planting, while SP-36 and $\mathrm{KCl}$ are given $100 \%$ as essential fertilizer.

Synthetic chemical fertilizer and MSC dosage per polybag were calculated by converting the fertilizer requirement per plant with a spacing of $50 \times 25 \mathrm{~cm}$ (Table 1).

Table 1. Doses of chemical fertilizers and MSC for basil plants per polybag until the age of 8 WAP

\begin{tabular}{|l|l|l|}
\hline \multirow{2}{*}{$\begin{array}{l}\text { Type of } \\
\text { Fertilizer }\end{array}$} & \multicolumn{2}{|c|}{ Fertilizer dose } \\
\cline { 2 - 3 } Urea & Per hectare & Per plant \\
\hline $\mathrm{SP}-36$ & $416.67 \mathrm{~kg} / \mathrm{ha}$ & $6.94 \mathrm{~g}$ \\
\hline $\mathrm{KCl}$ & $250.00 \mathrm{~kg} / \mathrm{ha}$ & $4.20 \mathrm{~g}$ \\
\hline $\mathrm{MSC}$ & $3846.2 \mathrm{~kg} / \mathrm{ha}$ & $64.1 \mathrm{~g}$ \\
\hline
\end{tabular}


Harvesting starts at the age of 4 weeks after planting (WAP) by cutting the young branches, $15 \mathrm{~cm}$ long. The harvest were carried out three times.

The variable observed were: plant growth (plant height, number of leaves, number of branches, the total length of branches, the diameter of stems, and leaf area). Leaf area was measured in the $5^{\text {th }}$ widest leaf from the shoot at 6 WAP using the gravimetric method. Other variables observed were fresh weight and dry weight of harvest, fresh and dry weight of shoots and roots. The quality components observed were chlorophyll content by spectrophotometry, vitamin $\mathrm{C}$ content by iodine titration, and leaf nitrate content monitored by a nitrate meter (LAQUAtwin-NO3-11, HORIBA Scientific).

\section{RESULTS AND DISCUSSION}

\subsection{Results}

\subsubsection{Soil Analysis and Organic Fertilizer}

The results of soil analysis of medium planting showed that the soil used had a neutral $\mathrm{pH}$ with a value of 7.64, organic and total nitrogen contents were low (1.94\%), while the $\mathrm{C} / \mathrm{N}$ ratio is considered moderate (0.13). The available range of $\mathrm{P} 2 \mathrm{O} 5$ was $68.10 \mathrm{mg} / \mathrm{g}$, $\mathrm{P} 2 \mathrm{O} 5$ potential, and $\mathrm{K} 2 \mathrm{O}$ potential very high with values of $159.23 \mathrm{mg} / 100 \mathrm{~g}$ and $117.53 \mathrm{mg} / 100 \mathrm{~g}$,
respectively.The soil criteria refer to Eviati and Sulaeman (2009) [17].

Analysis of organic fertilizers showed that Mexican sunflower compost contained $\mathrm{N}$ of $2.69 \%$, $\mathrm{P} 2 \mathrm{O} 50.99 \%$, and $\mathrm{K} 2 \mathrm{O} 4.96 \%$. The products are relatively low compared to the previous study [18] that $\mathrm{N}$ content of Mexican sunflower compost is $3.90 \%$, and Lestari [14] that Mexican sunflower contains 3.50-4.00\% $\mathrm{N}, 0.35-0.38 \% \mathrm{P}, 3.50-4.10 \% \mathrm{~K}$. The total $\mathrm{N}$ content in compost has decreased because composting for 25-30 days with materials that have a high $\mathrm{N}$ content [19].

\subsubsection{Growth and Production of Basil Plants Basil}

The Kadudampit 2 accession plant height was higher than the other accessions, but not significantly different from the Ciaruteun and Gasol accessions. Kemang accessions had no significant difference in leaf numbers with Gegerbitung, Kadudampit 2, and Cijujug, but significantly larger than other accessions. The number of shoots of 'Kadudampit 1' was higher than other accessions, but not significantly different from the 'Gegerbitung' and 'Kemang'. The diameter of 'Gasol' was larger than the other accessions, but not significantly different from 'Kadudampit2' basil. The leaf area of 'Gasol' was larger than the other accessions but not significantly different from the Ciaruteun (Table 2).

Table 2. Plant height, number of leaves, number of shoots, the total length of shoots, stem diameter, and leaf area of basil plants

\begin{tabular}{|c|c|c|c|c|c|c|}
\hline Treatment & $\begin{array}{c}\text { Plant } \\
\text { height }\end{array}$ & $\begin{array}{c}\text { Number of } \\
\text { leaves }\end{array}$ & $\begin{array}{l}\text { Number of } \\
\text { shoots }\end{array}$ & $\begin{array}{c}\text { The total length of } \\
\text { shoots }\end{array}$ & $\begin{array}{c}\text { Stem } \\
\text { diameter }\end{array}$ & Leaf area \\
\hline Accession & $(\mathbf{c m})$ & (strands) & (shoots) & $(\mathbf{c m})$ & $(\mathbf{m m})$ & $(\mathrm{cm} 2)$ \\
\hline Gegerbitung & $20: 31^{\mathrm{a}}$ & $119.64^{\mathrm{d}}$ & $11.50^{\mathrm{bc}}$ & 95.27 & $4: 45^{\mathrm{a}}$ & $22.92^{\mathrm{a}}$ \\
\hline Kadudampit 1 & $24.14^{\mathrm{b}}$ & $99.25^{\mathrm{bc}}$ & $12.42^{\mathrm{c}}$ & 105.55 & $5: 03^{a b}$ & $35.17^{\mathrm{c}}$ \\
\hline Kadudampit 2 & $29.47^{\mathrm{c}}$ & $113.93^{\mathrm{cd}}$ & $10.87^{\mathrm{ab}}$ & 103.15 & $5.73^{\mathrm{bc}}$ & $31.56^{\mathrm{bc}}$ \\
\hline Kemang & $23: 17^{\mathrm{b}}$ & $120.55^{\mathrm{d}}$ & $11.25^{\mathrm{bc}}$ & 93.05 & $4.64^{\mathrm{a}}$ & $27.85^{\mathrm{ab}}$ \\
\hline Ciaruteun & $27.20^{\mathrm{c}}$ & $97.56^{\mathrm{b}}$ & $11.56^{\mathrm{bc}}$ & 93.31 & $5: 27^{\mathrm{ab}}$ & $45.03^{\mathrm{d}}$ \\
\hline Cijujug & $22.75^{b}$ & $112.15^{\mathrm{bcd}}$ & $10.61^{\mathrm{ab}}$ & 98.12 & $4.85^{\mathrm{ab}}$ & $29.41^{a b c}$ \\
\hline Gasol & $27.85^{\mathrm{c}}$ & $79.12^{\mathrm{a}}$ & $9.75^{\mathrm{a}}$ & 81.17 & $6: 29^{c}$ & $48.14^{\mathrm{d}}$ \\
\hline \multicolumn{7}{|c|}{ Fertilizer Composition } \\
\hline $100 \% \mathrm{Ua}$ & $27.36^{\mathrm{b}}$ & 113.96 & $11: 49$ & $104.95^{\mathrm{bc}}$ & $5: 17$ & $39.71^{b}$ \\
\hline $100 \% \mathrm{MSC}$ & $27.10^{\mathrm{b}}$ & 103.52 & $10: 46$ & $92.95^{\mathrm{b}}$ & $5: 17$ & $39.03^{b}$ \\
\hline $75 \% \mathrm{Ua}+25 \% \mathrm{MSC}$ & $25.89^{b}$ & 109.76 & $12: 21$ & $111.20^{\mathrm{c}}$ & 5.63 & $35.48^{\mathrm{b}}$ \\
\hline $50 \% \mathrm{Ua}+50 \% \mathrm{MSC}$ & $26.66^{b}$ & 105.92 & 10.90 & $103.55^{\mathrm{bc}}$ & $5: 06$ & $35.85^{\mathrm{b}}$ \\
\hline $25 \% \mathrm{Ua}+75 \% \mathrm{MSC}$ & $25.58^{\mathrm{b}}$ & 108.54 & 10.67 & $94.14^{\mathrm{b}}$ & 4.93 & $34.60^{\mathrm{b}}$ \\
\hline $0 \% \mathrm{Ua}+0 \% \mathrm{MSC}$ & $17.32^{\mathrm{a}}$ & 94.47 & 11.12 & $67.18^{a}$ & 5.12 & $21.11^{\mathrm{a}}$ \\
\hline
\end{tabular}

Means along the column with the same superscript are not significantly different by DMRT $(\mathrm{p}=0.05)$

Ua: urea, MSC: Mexican sunflower compost

Plant height, the total length of shoots, and leaf area of basil plants given various compositions of Mexican sunflower fertilizers were not significantly different from those shown Urea $100 \%$, but more significant than non fertlilized $\mathrm{N}$. The number of leaves, number of shoots, and stem diameter were not significantly different among the various $\mathrm{N}$ fertilizer compositions (Table 2).
The fresh and dry weight of Gasol accession was not significantly different from that of Kadudampit2. The fresh and dry weight of Kadudampit 2 accession roots The fresh weight of the 'Kadudampit 2' canopy was heavier than 'Kemang' and 'Cijujug', while the canopy dry weight did not differ between accessions (Table 3 ). 
Table 3. Fresh and dry weight of harvesting, shoots, and roots of basil plants

\begin{tabular}{|c|c|c|c|c|c|c|}
\hline \multirow{2}{*}{ Treatment } & \multicolumn{2}{|c|}{ Harvesting weight (g) } & \multicolumn{2}{|c|}{ Root weight (g) } & \multicolumn{2}{|c|}{ Canopy weight (g) } \\
\hline & Fresh & dry & fresh & Dry & Fresh & Dry \\
\hline \multicolumn{7}{|l|}{ Accession } \\
\hline Gegerbitung & $47.02^{\mathrm{ab}}$ & $6.09^{\mathrm{a}}$ & $9.36^{\mathrm{a}}$ & $3.63^{\mathrm{ab}}$ & $131.60^{\mathrm{bc}}$ & 32.44 \\
\hline Kadudampit 1 & $51.45^{\text {bcd }}$ & $6.37^{\mathrm{a}}$ & $6.70^{\mathrm{a}}$ & $2.78^{\mathrm{a}}$ & $114.54^{\mathrm{abc}}$ & 29.61 \\
\hline Kadudampit 2 & $55.94^{\mathrm{de}}$ & $7: 46^{b}$ & $13: 40^{\mathrm{b}}$ & $4.82^{b}$ & $168.12^{\mathrm{c}}$ & 40.24 \\
\hline Kemang & $44.04^{\mathrm{a}}$ & $6: 10^{\mathrm{a}}$ & $7: 08^{\mathrm{a}}$ & $2.76^{\mathrm{a}}$ & $76.97^{\mathrm{a}}$ & $23: 39$ \\
\hline Ciaruteun & $53.57^{\mathrm{cd}}$ & $6.68^{\mathrm{ab}}$ & $8: 56^{\mathrm{a}}$ & $3: 16^{\mathrm{a}}$ & $135.57^{\mathrm{abc}}$ & 31.16 \\
\hline Cijujug & $48.79^{\mathrm{abc}}$ & $6: 59^{\mathrm{ab}}$ & $7.71^{\mathrm{a}}$ & $3.08^{\mathrm{a}}$ & $101.25^{\mathrm{ab}}$ & 27.88 \\
\hline Gasol & $60.21^{\mathrm{e}}$ & $7.38^{\mathrm{b}}$ & $8.69^{a}$ & $3.31^{\mathrm{a}}$ & $125.38^{\mathrm{abc}}$ & 29.99 \\
\hline \multicolumn{7}{|l|}{ Fertilizer composition } \\
\hline $100 \% \mathrm{Ua}$ & $56.58^{\mathrm{c}}$ & $7.40^{\mathrm{c}}$ & 9.39 & $3.41^{\mathrm{abc}}$ & $117.69^{\mathrm{b}}$ & $30.52^{\mathrm{bc}}$ \\
\hline $100 \% \mathrm{MSC}$ & $54.83^{\mathrm{bc}}$ & $7.16^{\mathrm{bc}}$ & 8.48 & $3.16^{\mathrm{ab}}$ & $118.31^{\mathrm{b}}$ & $26.02^{\mathrm{b}}$ \\
\hline $75 \% \mathrm{Ua}+25 \% \mathrm{MSC}$ & $53.60^{\mathrm{bc}}$ & $6.95^{\mathrm{bc}}$ & 10.78 & $4.36^{\mathrm{c}}$ & $192.45^{\mathrm{c}}$ & $44.36^{\mathrm{d}}$ \\
\hline $50 \% \mathrm{Ua}+50 \% \mathrm{MSC}$ & $51.37^{\mathrm{b}}$ & $6.80^{\mathrm{bc}}$ & 8.42 & $3.48^{\mathrm{bc}}$ & $122.33^{\mathrm{b}}$ & $34.53^{\mathrm{cd}}$ \\
\hline $25 \% \mathrm{Ua}+75 \% \mathrm{MSC}$ & $50.78^{\mathrm{b}}$ & $6.51^{\mathrm{b}}$ & 8.74 & $3.21^{\mathrm{ab}}$ & $104.67^{\mathrm{ab}}$ & $30.83^{\mathrm{bc}}$ \\
\hline $0 \% \mathrm{Ua}+0 \% \mathrm{MSC}$ & $42.30^{\mathrm{a}}$ & $5.18^{\mathrm{a}}$ & 7.18 & $2.54^{\mathrm{a}}$ & $76.05^{\mathrm{a}}$ & $17.76^{\mathrm{a}}$ \\
\hline
\end{tabular}

Means along the column with the same superscript are not significantly different by DMRT $(\mathrm{p}=0.05)$

Ua: urea, MSC: Mexican sunflower compost

The fresh and dry weight of harvest, roots, and canopy of plants shown $100 \%$ MSC was not significantly different from those given $100 \%$ Urea, as well as those given composition of $75 \%$ Urea $+25 \%$ MSC, even fresh and dry weight. The canopy of plants given this fertilizer composition more significant than those shown $100 \%$ Urea.

\subsubsection{Quality of Basil Leaves}

The quality of basil leaves (content of nitrate and vitamin C) were significantly influenced by fertilizer's composition. Plants treated with $100 \%$ Urea showed the highest nitrate content, not substantially different from those given $25 \%$ Urea $+75 \%$ MSC, in comparison, plants treated with $100 \%$ MSC and not N fertilization showd the lowest nitrate content (Table 5). The content of vitamin C in $\mathrm{N}$ fertilizers' various compositions was not significantly different, but substantially higher than plant without $\mathrm{N}$ fertilizer (Table 4).

The pigment content of chlorophyll a, chlorophyll $\mathrm{b}$, carotene, and total chlorophyll was significantly affected by accession treatment and fertilizer composition, while anthocyanin content was not affected. Basil leaves of 'Kemang' contain chlorophyll a, chlorophyll b, total chlorophyll, and carotene higher compared to Gasol and Kadudampit1. Basil plants treated with $100 \%$ Urea fertilizer composition show the highest content of chlorophyll a, chlorophyll b, total chlorophyll, and carotene, followed by the composition of a mixture of Urea + MSC, while the plants treated with $100 \%$ MSC and those not given $\mathrm{N}$ fertilizers had the lowest pigment content (Table 5).

Table 4. The content of nitrates and vitamin $\mathrm{C}$ of basil leaves

\begin{tabular}{|l|r|r|}
\hline Treatment of & Nitrate & \multicolumn{1}{|c|}{$\begin{array}{c}\text { Vitamin } \\
\text { C }\end{array}$} \\
\hline Accession & 94.52 & 1818.50 \\
\hline Gegerbitung & 1755.50 & 94.52 \\
\hline Kadudampit 1 & 1883.30 & 88.30 \\
\hline Kadudampit 2 & 92.74 & 1740.70 \\
\hline Kemang & 2079.60 & 87.70 \\
\hline Ciaruteun & 96.30 & 1649.20 \\
\hline Cijujug & 99.56 & 1888.80 \\
\hline Gasol & $2373.0^{\mathrm{c}}$ & $99.80^{\mathrm{b}}$ \\
\hline Fertilizer Composition & $1358.0^{\mathrm{a}}$ & $96.76^{\mathrm{b}}$ \\
\hline $100 \%$ Ua & $1957.1^{\mathrm{b}}$ & $97.02^{\mathrm{b}}$ \\
\hline $100 \% \mathrm{MSC}$ & $1888.8^{\mathrm{b}}$ & $94.73^{\mathrm{b}}$ \\
\hline $75 \% \mathrm{Ua}+25 \% \mathrm{MSC}$ & $2073.0^{\mathrm{bc}}$ & $94.98^{\mathrm{b}}$ \\
\hline $50 \% \mathrm{Ua}+50 \% \mathrm{MSC}$ & $1334.9^{\mathrm{a}}$ & $76.95^{\mathrm{a}}$ \\
\hline $25 \% \mathrm{Ua}+75 \% \mathrm{MSC}$
\end{tabular}

Means along the column with the same superscript are not significantly different by DMRT ( $\mathrm{p}=0.05$ )

Ua: urea, MSC: Mexican sunflower compost 
Table 5. Content Pigment of basil plants

\begin{tabular}{|c|c|c|c|c|c|}
\hline \multirow{2}{*}{ Treatment } & \multicolumn{5}{|c|}{$\begin{array}{c}\text { Leaf pigment content }\left(\mathrm{mg}^{-g^{-1}}\right) \\
\end{array}$} \\
\hline & Chlorophyll a & Chlorophyll b & Anthocyanin & Carotenoids & Chlorophyll Total \\
\hline \multicolumn{6}{|l|}{ Accession } \\
\hline Gegerbitung & $1.62^{\mathrm{cd}}$ & $0.84^{\mathrm{c}}$ & 0.04 & $0.48^{\mathrm{bc}}$ & $2.45^{\mathrm{c}}$ \\
\hline Kadudampit I & $1.51^{\mathrm{bc}}$ & $0.77^{\mathrm{bc}}$ & 0.05 & $0.42^{\mathrm{ab}}$ & $2.28^{\mathrm{bc}}$ \\
\hline Kadudampit II & $1.67^{\mathrm{cd}}$ & $0.83^{\mathrm{c}}$ & 0.02 & $0.48^{\mathrm{bc}}$ & $2.50^{\mathrm{c}}$ \\
\hline Kemang & $1.75^{\mathrm{d}}$ & $0.87^{\mathrm{c}}$ & 0.04 & $0.49^{\mathrm{c}}$ & $2.62^{\mathrm{c}}$ \\
\hline Ciaruteun & $1.33^{\mathrm{ab}}$ & $0.68^{\mathrm{ab}}$ & 0.04 & $0.40^{\mathrm{a}}$ & $2.01^{\mathrm{ab}}$ \\
\hline Cijujug & $1.63^{\mathrm{cd}}$ & $0.83^{\mathrm{c}}$ & 0.08 & $0.43^{\mathrm{abc}}$ & $2.46^{\mathrm{c}}$ \\
\hline Gasol & $1.27^{\mathrm{a}}$ & $0.63^{\mathrm{a}}$ & 0.01 & $0.38^{\mathrm{a}}$ & $1.90^{\mathrm{a}}$ \\
\hline \multicolumn{6}{|l|}{ Fertilizer composition } \\
\hline $100 \% \mathrm{Ua}$ & $1.92^{\mathrm{c}}$ & $0.95^{\mathrm{c}}$ & 0.04 & $0.52^{\mathrm{c}}$ & $2.88^{\mathrm{c}}$ \\
\hline $100 \% \mathrm{MSC}$ & $1.23^{\mathrm{a}}$ & $0.63^{\mathrm{a}}$ & 0.08 & $0.35^{\mathrm{a}}$ & $1.88^{\mathrm{a}}$ \\
\hline $75 \% \mathrm{Ua}+25 \% \mathrm{MSC}$ & $1.62^{\mathrm{b}}$ & $0.84^{\mathrm{b}}$ & 0.05 & $0.48^{\mathrm{bc}}$ & $2.46^{\mathrm{b}}$ \\
\hline $50 \% \mathrm{Ua}+50 \% \mathrm{MSC}$ & $1.55^{\mathrm{b}}$ & $0.78^{\mathrm{b}}$ & 0.03 & $0.44^{\mathrm{b}}$ & $2.33^{\mathrm{b}}$ \\
\hline $25 \% \mathrm{Ua}+75 \% \mathrm{MSC}$ & $1.62^{\mathrm{b}}$ & $0.83^{\mathrm{b}}$ & 0.02 & $0.48^{\mathrm{bc}}$ & $2.45^{\mathrm{b}}$ \\
\hline $0 \% \mathrm{Ua}+0 \% \mathrm{MSC}$ & $1.27^{\mathrm{a}}$ & $0.64^{\mathrm{a}}$ & 0.02 & $0.37^{\mathrm{a}}$ & $1.91^{\mathrm{a}}$ \\
\hline
\end{tabular}

Means along the column with the same superscript are not significantly different by DMRT $(\mathrm{p}=0.05)$

\subsection{DISCUSSION}

\subsubsection{Growth and Production of Basil Plants}

Basil accessions in this study can be distinguished on small leaves (Gegerbitung, Kemang, and Cijujug) and broad leaves (Kadudampit1, Kadudampit2 Ciaruteun, and Gasol). Accessions of broad-leaves basil had significantly higher yields on the variables of plant height, stem diameter, and leaf area. Still, they had the lower number of leaves, the number of the shoot, and the total length of shoots compared to accessions with small leaves, except for Kadudampit 2 accession because Kadudampit 2 accession began to appear leafy width at 4 WAP. This related to translocation of photosynthate to the part of plant growth [20]. The photosynthate of broadleaf basil accession is allocated more to leaf size than to the number of leaves, the number of shoots, and total length of shoots.

Basil is a leafy vegetable, so the number of leaves, the number and the length of shoots affect the productivity of the basil plant. The 'Gasol' harvest fresh weight was significantly higher than other accessions, because 'Gasol' had the largest leaf size compared to different accessions. Plant with broad leaves will be able to absorb more sunlight, thus increasing photosynthetic rate, and affecting plant growth [21]. This following Gigir et al. (2014) [22], which states that the taller the plant, the longer and broader the leaves, the greater the yield.

Plants treated with $\mathrm{N}$ fertilizers showed better growth and production responses than those not fertilized. The results of Damayanti's (2017) [23] research show that nitrogen application has a significant effect on the height of the basil plant. According to Aziz and Kurnia (2015), sufficient nitrogen supply to plants can accelerate plant vegetative growth, both on stems, branches, and leaves. The growth and production of basil plants treated of MSC or combined with Urea were not significantly different. This results showed that MSC can substitute or complement for Urea. This related to the ability of MSC to improve soil physical and chemical properties. Mexican sunflower green manure can change the physical properties (reduce the soil density) and chemical properties (increase the content of C-organic, N-total, available-P and $\mathrm{K}$ interchangeable) soil, and increase the fresh weight of cabbage flowers [24].

The provision of inorganic fertilizers combined with organic fertilizers can respond to increased growth of basil plants [22]. Sulaeman et al. [25] also showed that the application of organic fertilizers (manure or sludge) combined with synthetic fertilizers resulted in higher plant growth and higher maize plant residues. Kurnia et al. [26] reported that the production of tomato plants given 30 ton.ha ${ }^{-1}$ grass compost and 15 ton.ha ${ }^{-1}$ grass compost + $50 \%$ synthetic fertilizer dose was higher than control.

Basil plants treated without $\mathrm{N}$ fertilizer $(0 \% \mathrm{Ua}+$ $0 \%$ MSC) showed the lowest growth and production compared to other treatments. This related to the low nitrogen content of the soil used for research, namely $0.13 \%$, so it requires additional elements in the form of fertilizer.

\subsubsection{Quality of Treated Basil Plants}

Plant leaves that fertilized by $100 \%$ Urea, showed the highest nitrate content. This following reported of Liu etal. [27] that lettuce treated with inorganic fertilizers hada higher nitrate concentration reaching $5000-6100 \mathrm{mg} / \mathrm{kg}$, when compared to organic fertilizer lettuce, namely 4300$5200 \mathrm{mg} / \mathrm{kg}$. This because the Urea used will immediately hydrolyze and undergo a nitrification process to form $\mathrm{NH}_{4}{ }^{+}$and $\mathrm{NO}_{3}{ }^{-}$ions .

Nitrate and nitrite levels in vegetables can vary due to the use of fertilizers and biotic, and abiotic factors. Continuous use of inorganic fertilizers will accumulate in the soil so that nitrate levels will increase and vegetables 
tend to have high nitrate levels. . These condition needs to be watched out because the estimated total average intake of nitrate consumed is around $61 \mathrm{mg} /$ person/day (range $24-102 \mathrm{mg} / \mathrm{person} /$ day), and vegetables contribute around $75 \%$ [28].

The application of MSC makes the nitrate content in basil leaves low. This one of the advantages of MSC because vegetables with low nitrate levels are safer for human consumption. Plants treated with various composition of Urea show a higher content of vitamin $\mathrm{C}$ compared to non-fertilized. Presumably this is caused by nitrogen from the composition of the fertilizers relatively sufficient for formation of leaf chlorophyll, thus contributing to increasing the rate of photosynthesis. Plants used photosynthate in the form of glucose $(\mathrm{C} 6 \mathrm{H} 12 \mathrm{O} 6)$ as a precursor for the formation of vitamin $\mathrm{C}$ and other chemical compounds [29].

The mainstay of treatment compared to other treatments. Presumably this condition related to time offering MSC, which is only done once a week before planting, while Urea is given gradually as essential fertilizer, at the age of 3 and 6 weeks after planting.

The total chlorophyll a and b content in this study were relatively low, about 1.90 - 2.88. Basil has a low range because it is an annual plant. The leaves are small with thin leaves. This is following to Fahn (1982) [30], which states that leaves basil are only composed of one palisade tissue layers. Mesophyll, especially palisade tissue, is anetwork that is rich in chlorophyll.

Chlorophyll and carotene pigments are located in chloroplasts and play a role in the photosynthesis process. Carotene can protect chlorophyll from high light intensity [31]. The results showed that there was a link between carotene and chlorophyll. Raisawati (2018) [32] showed a correlation between the two; an increase in carotene levels related to an increase in chlorophyll levels.

\section{CONCLUSION}

Kadudampit2 and Gasol accessions can be developed because they show plant height, fresh weight, and dry weight greater than other accessions. The application of MSC and its combination with Urea showed growth, production and quality equivalent to those treated with Urea. MSC can reduce the nitrate levels absorbed by plants, making it safer to consumed and can improve soil fertility. The treatment of $75 \% \mathrm{~N}$-Urea and $25 \% \mathrm{~N}$ - Mexican sunflower can be an alternative fertilizer that can be used for basil plants because it can balance several aspects both in terms of productivity, economy, and environment.

\section{ACKNOWLEDGMENTS}

Thank you to the Directorate General of Higher Education, Ministry of Education and Culture of the Republic of Indonesia for research funding assistance through the 2019 Higher Education Excellence Applied Research Grant.

\section{REFERENCES}

[1] S. Khan et al., "Phytochemical Constituents and Pharmacological Activities of Sweet Basil- Ocimum basilicum L . ( Lamiaceae )," vol. 23, no. 9, pp. 3773-3782, 2011.

[2] A. Guaadaoui, S. Benaicha, and N. Elmajdoub, "What is a bioactive compound? A combined definition for a preliminary consensus," no. April, 2015

[3] A. F. Blank et al., "A diallel study of yield components and essential oil constituents in basil (Ocimum basilicum L.)," Ind. Crops Prod., vol. 38, pp. 93-98, 2012.

[4] D. N. Nuraini, Aneka daun berkhasiat untuk obat. Yogyakarta: Gava Media, 2014.

[5] U. S. D. A. [USDA], "Ocimum basilicum L.," 2018. [Online]. Available: https://fdc.nal.usda.gov/fdcapp.html\#/food-details/172232/nutrients. [Accessed: 29-Apr-2020].

[6] R. N. Wierdak, E. Rozek, and K. Dzida, "Growth response to nitrogen and potassium fertilization of common basil (Ocimum basilicum L .) Plants," vol. 11, no. 2, pp. 275-288, 2012.

[7] K. Singh, P. P. Singh, S. U. Beg, D. Kumar, and D. D. Patra, "Effect of NPK fertilizers on growth, oil yield and quality of French basil (Ocimum basilicum L)," J. Aromatic and Spices Crops, vol. 13, no. 1, pp. 52-54, 2004.

[8] A. Barker and D. Pilbeam, Nitrogen. In Barker AV, Pilbeam DJ (Eds.). Handbook of Plant Nutrition. Boca Raton: CRC Press. Taylor and Francis Group., 2007.

[9] Endrizal and J. Bobihoe, "Efisiensi penggunaan pupuk nitrogen dengan penggunaan pupuk organik pada tanaman padi sawah," J. Pengkajian dan Pengembangan Teknologi Pertanian, vol. 7, no. 2, pp. 118-124, 2004.

[10] A. S. Wahid, "Peningkatan efisiensi pupuk nitrogen pada padi sawah dengan metode bagan warna daun," J. Penelitian dan Pengembangan Pertanian, vol. 22, no. 1999,2003

[11] L. M. Purba, T. Ashar, and D. N. Santi, "Pola Pemupukan dan Analisa Kandungan Nitrat pada Sayur Brokoli (Brassica oleracea cv. brocoli) di Pertanian Desa Merdeka Kecamatan Merdeka Kabupaten Karo Tahun 2012,” pp. 1-9, 2012.

[12] W. Safitri, R. S. Pujiati, and P. T. Ningrum, "Kandungan nitrat pada air tanah di sekitar lahan pertanian padi, palawija dan tembakau," Artikel ilmiah Hasil Penelitian Mahasiswa, 2014.

[13] M. Nurrohman, A. Suryanto, and K. Puji, "Penggunaan Fermentasi Ekstrak Paitan (Tithonia diversifolia L.) dan Kotoran Kelinci Cair Sebagai Sumber Hara Pada Budidaya Sawi (Brassica juncea L .) Secara Hidroponik Rakit Apung," J. Produksi Tanam., vol. 2, no. 8, pp. 649-657, 2014.

[14] S. A. D. Lestari, M. Melati, and H. Purnamawati, "Penentuan Dosis Optimum Pemupukan N, P, dan K 
pada Tanaman Kacang Bogor [Vigna subterranea (L.) Verdcourt]," J. Agron. Indones. (Indonesian J. Agron., vol. 43, no. 3, p. 193, 2016.

[15] T. S. Rahardian, T. Sumarni, and A. Suryanto, "Pemanfaatan pupuk hijau paitan (Tithonia diversifolia ) dan krinyu (Chromolaena odarata) dalam peningkatan hasil tanaman brokoli (Brassica oleracea)"Planta Tropica vol. 2, no. 2, pp. 108-116, 2017.

[16] BMKG, Analisis Hujan Februari 2020 dan Prakiraan Hujan April, Mei dan Juni 2020. Jakarta, 2020.

[17] Eviati and Sulaeman, Analisis Kimia Tanah, Tanaman, Air, dan Pupuk. Bogor: Balai Penelitan Tanah, 2009.

[18] A. Rahayu, W. Nahraeni, N. Rochman, and A. Faturrochman, " respon pertumbuhan aksesi kemangi pada berbagai komposisi pupuk nitrogen alami" J. Agronida, vol. 5, no.2, pp 70-77, 2019.

[19] A. Arifiati, Syekhfani, and Y. Nuraini, "Uji Efektifitas Perbandingan Bahan Kompos Paitan (Tithonia Diversifolia) Tumbuhan Paku (Dryopteris Filixmas) dan Kotoran Kambing Terhadap Serapan N Tanaman Jagung Pada Inceptisol," J. Tanah dan Sumberd. Lahan, vol. 4, no. 2, pp. 543-552, 2017.

[20] Hermansyah, Y. Sasmita, and E. Inoriah, "Penggunaan pupuk daun dan manipulasi jumlah cabang yang ditinggalkan pada panen kedua tanaman nilam," Akta Agrosia, vol. 12, pp. 194-203, 2009.

[21] H. B. Buntoro, R. Rogomulyo, and S. Trisnowati, "Pengaruh takaran pupuk kandang dan intensitas cahaya terhadap pertumbuhan dan hasil temu putih (Curcuma zedoaria L)," Vegetalika, vol. 3, no. 4, pp. 29-39, 2014.

[22] S.F. Gigir, J. J. Rondonuwu, W. J. N. Kumolontang, dan Rafli I. Kawulusan, "Respons pertumbuhan kemangi (Ocimum sanctum L.) terhadap pemberian pupuk organik dan anorganik,"Cocos, vol. 5, no. 3, pp 2014.

[23] D. P. O. Damayanti, "Pengaruh ammonium (NH4+) dan nitrat (NO3-) terhadap pertumbuhan dan kandungan minyak atsiri tanaman kemangI (Ocimum basilicum) dengan sistem hidroponik," Unoversitas Jember, 2017.

[24] Hafifah, Sudiarso, M. . Maghfoer, and B. Prasetya, "The potential of Tithonia diversifolia green manure for improving soil quality for cauliflower (Brassica oleracea var. botrytis L.)," Jorurnal Degrad. Min. Lands Manag., vol. 3, no. 2, pp. 499-506, 2016.

[25] Y. Sulaeman, Maswar, and D. Erfandi, "Effect of a combination of organic and inorganic fertilizers on soil chemical properties and yield of maize on acid dry land," J. Assess. Tech Dev. Pert., vol. 20, no. 1, pp. 1-12, 2017.

[26] S. Kurnia, N. Setyowati, and Alnopri, "The effect of combined doses of weed compost and synthetic fertilizers on the growth and yield of tomato (Lycopersicum esculentum Mill.)," J. Pert Sci., vol. 21, no. 1, pp. 15-21, 2019.

[27] C.W. Liu, Y. Sung, B.C. Chen, H.Y. Lai, "Effects of nitrogen fertilizers on the growth and nitrate content of lettuce (Lactuca sativa L.)", Int. J. Environment. Res. and Public Health, vol. 11, no. 4, pp. 4427-4440, 2014.

[28] J. M. Hill, Nitrates and Nitrites in Food and Water. Camridge: Woodhead Publishing Limited, 1996.

[29] R. Novitasari, "Proses Respirasi Seluler Pada Tumbuhan," Pros. Semin. Nas. Pendidik. Biol. dan Biol., pp. 89-96, 2017.

[30] A. Fahn, Anatomi Tumbuhan, vol. 3, no. 1. Semarang: Gadjah Mada University Press, 1982.

[31] C. Pebrianti, R. B. Ainurrasyid, L. Purnamaningsih, R. Leaf, and B. Merah, "Uji kadar antosianin dan hasil enam varietas tanaman bayam merah ( Alternanthera amoena Voss.) Pada Musim Hujan," J. Produksi Tanam., vol. 3, no. 1, pp. 27-33, 2015.

[32] T. Raisawati, "Kadar total klorofil, karoten, antosianin dan vitamin C tempuyung (Sonchus arvensis L .) pada cara panen berbeda," Prosiding Seminar Nasional LPPM UNiversitas Negeri Surabaya, July, pp. 729-736, 2018. 